\title{
Alopecia areata, morphea and psoriasis
}

\author{
Łysienie plackowate, twardzina ograniczona i łuszczyca
}

Koray Durmaz, Arzu Ataseven, Illkay Özer, Pembe Oltulu

Department of Dermatology, Faculty of Medicine, Necmettin Erbakan University Meram, Turkey

Dermatol Rev/Przegl Dermatol 2020, 107, 289-291

DOI: https://doi.org/I 0.5 I |4/dr.2020.9776 |

Morphea, also called localized scleroderma, is a benign skin condition that affects only the skin and gradually resolves in 3 to 5 years, even spontaneously. It presents classically as an indurated, annular plaque with a peripheral lilac ring [1]. Alopecia areata is a cause of non-scarring hair loss and it affects the skin by T-cell-mediated autoimmunity, though the exact pathogenesis is still unclear. It can be associated with other diseases including psoriasis [2]. Psoriasis is a common, inflammatory skin disorder characterized by scaly erythematous plaques and it can be associated with numerous diseases due to its immune-mediated effects [3].

We report a morphea case that had been diagnosed accompanying psoriasis and also alopecia areata. The coexistence of morphea, alopecia areata and psoriasis was not reported in the literature before.

A 36-year-old female patient referred for evaluation of violaceous and depressed appearance on both the legs that were noticed by her 1 year before (fig. 1). She has had a psoriasis history for 10 years (and alopecia areata for 6 months (fig. 2). She does not have family history of a dermatological disease. At the dermatological examination, there were many various shaped and sized violaceous or brownish patches on the thighs and gluteal region. She had alopecia areata on the scalp. Her psoriatic lesions were in the post-inflammatory phase and limited on the knees and elbows. The PASI score was calculated as 1.8. Her routine laboratory tests including complete blood count, glucose, liver enzymes, urea, and creatinine were normal. Antinuclear antibody (ANA), rheumatoid factor, anticentromere antibodies, anti-TOPO-1 and antiCCP antibodies were negative. Biopsy was taken from the violaceous depressed area on the left thigh. Histopathological examination showed that densely packed collagen bands in the deep reticular dermis presented parallel to the dermoepidermal junction (fig. 3). Clinical and histopathological features were consistent with morphea. Topical calcipotriol betamethasone combination ointment twice a day for psoriatic plaques, tacrolimus $0.1 \%$ ointment once a day and methotrexate $15 \mathrm{mg}$ per week sc. for the morphea plaques and psoriatic plaques,
Twardzina ograniczona (morphea) to łagodne schorzenie, które charakteryzuje się występowaniem zmian ograniczonych wyłącznie do skóry. Ogniska chorobowe stopniowo i nawet samoistnie zanikają w czasie 3-5 lat. W klasycznym obrazie choroby stwierdza się obecność stwardniałych, obrączkowatych ognisk w postaci blaszek otoczonych sinofioletową obwódką [1]. Łysienie plackowate jest chorobą, która powoduje niebliznowaciejącą utratę włosów. Patogeneza schorzenia nie została dotąd dokładnie poznana, jednak zmiany na skórze są skutkiem procesu autoimmunizacji z udziałem limfocytów T. Łysienie plackowate może współwystępować z innymi chorobami, m.in. łuszczycą [2]. Łuszczyca jest powszechnym schorzeniem skóry, które może towarzyszyć wielu innym chorobom, prawdopodobnie wskutek oddziaływań o podłożu immunologicznym [3].

Przedstawiamy przypadek twardziny ograniczonej współistniejącej z łuszczycą oraz łysieniem plackowatym. Dotychczas w piśmiennictwie nie opisywano współistnienia tych trzech chorób.

Kobieta w wieku 36 lat zgłosiła się do kliniki ze względu na obecność zagłębionych ognisk o barwie sinofioletowej na skórze obu kończyn dolnych. Zmiany te zostały zauważone przez pacjentkę rok wcześniej (ryc. 1). W wywiadzie stwierdzono łuszczycę utrzymującą się od 10 lat oraz łysienie plackowate od 6 miesięcy (ryc. 2). Wywiad rodzinny w kierunku chorób skóry był ujemny. W badaniu dermatologicznym wykazano liczne ogniska chorobowe o różnym kształcie i wielkości, o sinofioletowym lub brązowawym zabarwieniu, zlokalizowane na skórze ud i pośladków. Na skórze głowy obserwowano łysienie plackowate. Zmiany łuszczycowe ustąpiły z przebarwieniami pozapalnymi, a ich zasięg był ograniczony do skóry kolan i łokci. PASI score wynosił 1,8. W standardowych badaniach laboratoryjnych (morfologia krwi, stężenie glukozy, enzymy wątrobowe, mocznik i kreatynina) nie wykazano odchyleń od normy. Oznaczenia przeciwciał przeciwjądrowych (ANA), czynnika reumatoidalnego, przeciwciał przeciw centromerom, przeciwciał anty-TOPO-1 i anty-CCP dały wyniki ujemne. Pobrano wycinek z sinofioletowego, zagłębionego ogniska na skórze lewego uda. W badaniu histopatologicznym wykazano zagęszczone pasma kolagenu w głębszej części 


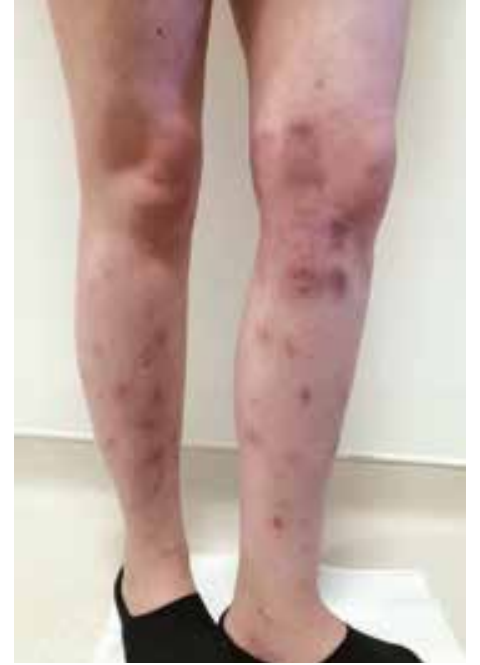

Figure I. Violaceous and depressed appearance on the bilateral thighs and legs

Rycina I. Sinofioletowe, zagłębione blaszki umiejscowione obustronnie na skórze ud i kończyn

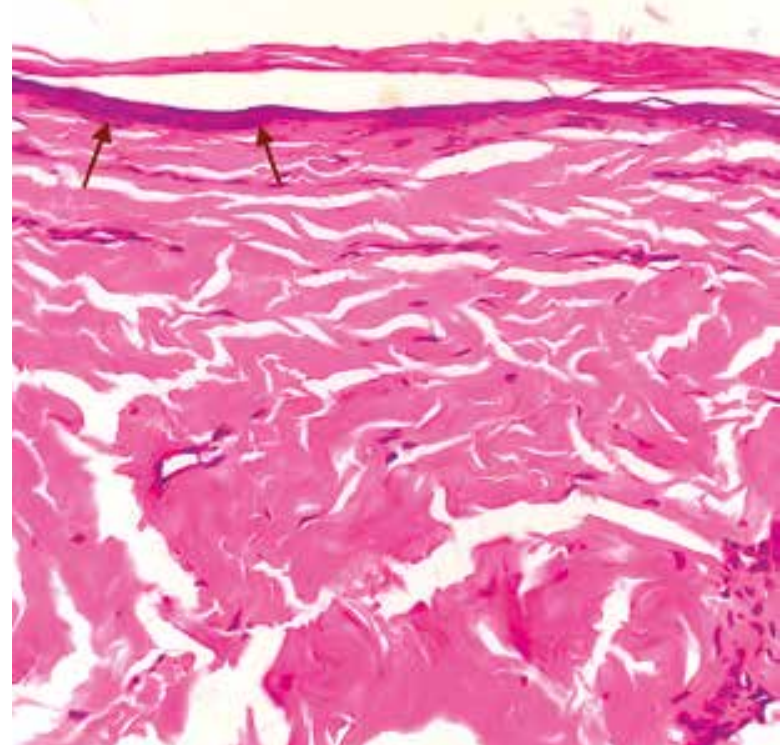

Figure 3. Magnification 400x, H\&E, densely packed collagen bands in the deep reticular dermis and thinned epidermis on the surface (arrow)

Rycina 3. Powiększenie 400×, barwienie H\&E, zagęszczone pasma kolagenu w głębszej części warstwy siateczkowej skóry właściwej i ścieńczały naskórek na powierzchni (strzałka)

and minoxidil 5\% spray 5-puff twice a day for alopecia areata were administered to the patient after the diagnosis and she is under follow-up.

Morphea is commonly seen alone, whereas psoriasis is an immune-mediated disease that is most frequently associated with morphea, approximately in $11.6 \%$ of cases [4]. Although the etiopathogenesis of these two diseases are still unclear, an underlying genetic basis, immunological T-cell defects, autoimmunity [5] and trauma can play a role regarding a provocative agent in both morphea and psoriasis (Koebner phenomenon).

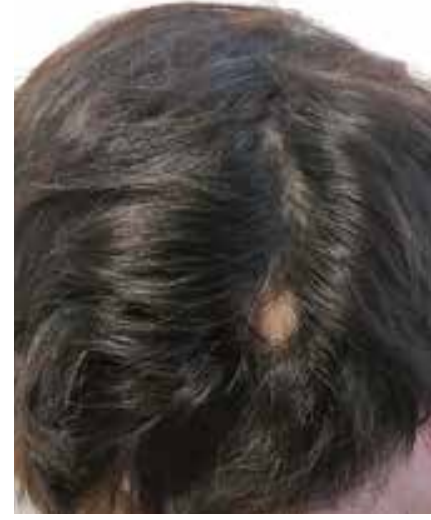

Figure 2. Alopecia areata on the scalp

Rycina 2. Łysienie plackowate na skórze głowy

warstwy siateczkowej skóry właściwej, ułożone równolegle do połączenia skórno-naskórkowego (ryc. 3). Obraz kliniczny i histopatologiczny odpowiadał twardzinie ograniczonej. Po zakończeniu diagnostyki u pacjentki wdrożono leczenie obejmujące maść zawierającą kalcypotriol i betametazon do stosowania 2 razy dziennie miejscowo na blaszki łuszczycowe, takrolimus $0,1 \%$ maści raz dziennie, metotreksat w dawce $15 \mathrm{mg}$ tygodniowo, podawany podskórnie oraz minoksydyl 5\% w postaci sprayu (5 dawek 2 razy dziennie) w leczeniu łysienia plackowatego. Pacjentka pozostaje obecnie pod opieką poradni.

Twardzina ograniczona często występuje samodzielnie, natomiast najczęściej współwystępującą chorobą o podłożu immunologicznym (w ok. 11,6\% przypadków) jest łuszczyca [4]. Etiopatogeneza obu tych chorób nadal nie została do końca poznana, jednak podłoże genetyczne, defekty odporności w zakresie limfocytów T, autoimmunizacja [5] oraz uraz mogą być czynnikami wywołującymi zarówno w twardzinie ograniczonej, jak i łuszczycy (objaw Koebnera). Dodatnie miano przeciwciał przeciwjądrowych (ANA) występuje częściej u pacjentów z współistniejącą łuszczycą i twardziną ograniczoną. Obserwacja ta potwierdza hipotezę immunogenną [1]. Przypadek twardziny ograniczonej współistniejącej z łuszczycą, w którym uzyskano poprawę po zastosowaniu acytretyny, opisali Bilen i wsp. Autorzy wskazali na możliwą zależność między poprawą objawów skórnych w przebiegu twardziny ograniczonej i działaniem immunomodulującym lub ograniczeniem wytwarzania kolagenu wskutek działania kwasu retinowego [4]. W badaniu przeprowadzonym w Bochum (Niemcy) stwierdzono, że 38 (8,1\%) spośród 472 pacjentów z twardziną ograniczoną miało współistniejące choroby autoimmunologiczne. Do najczęściej występujących chorób autoimmunologicznych należały: choroba Hashimoto, reumatoidalne zapalenie stawów, łysienie plackowate i cukrzyca typu 1 [6]. W kilku badaniach potwierdzono, że łuszczyca ma podłoże autoimmunologiczne, które obejmuje obecność autoreaktywnych limfocytów T. Łuszczycy może towarzyszyć wiele innych chorób autoimmunologicznych, takich jak autoimmunologiczne choroby pęcherzowe, bielactwo, łysienie 
Antinuclear antibody (ANA) positivity is more prevalent in patients with both psoriasis and morphea. This finding also supports the immunogenic hypothesis [1]. A case of morphea and psoriasis that improved with acitretin treatment was reported by Bilen et al. They highlighted that improvement of the morphea lesions might be associated with an immunomodulatory effect or decrease in collagen production due to retinoic acid [4]. A study from Bochum, Germany revealed that $38(8.1 \%)$ of the 472 morphea patients had concomitant autoimmune diseases. The most frequent autoimmune diseases were Hashimoto thyroiditis, rheumatoid arthritis, alopecia areata, and type 1 diabetes mellitus [6]. Several studies have revealed that psoriasis has an autoimmune background that includes autoreactive $\mathrm{T}$ cell presence. $\mathrm{Nu}-$ merous other autoimmune diseases such as autoimmune bullous diseases, vitiligo, alopecia areata and thyroiditis can accompany psoriasis [3]. In a cohort study among 25341 psoriasis patients, a statistically significant association between alopecia areata and psoriasis was also noted $(\mathrm{OR}=2.5 ; 95 \%$ CI: 2.0-3.0) [7]. Alopecia areata in psoriatic patients is still controversial as to whether its occurs in the setting of coexistence or if it is an adverse drug reaction induced by anti-psoriatic agents such as infliximab, efalizumab, etanercept, alefacept, and cyclosporine [2].

In this case report we presented a good example of concomitancy of morphea, psoriasis and alopecia areata in the same patient. This coexistence was not reported in the literature before. Future studies are necessary to explain the possible relationship between these 3 disorders depending on the distinct pathways of the inflammatory process and autoimmunity.

\section{CONFLICT OF INTEREST}

The authors declare no conflict of interest. plackowate i zapalenie tarczycy [3]. W badaniu kohortowym z udziałem 25341 chorych na łuszczycę zaobserwowano również statystycznie istotną zależność między łuszczycą i łysieniem plackowatym $(\mathrm{OR}=2,5 ; 95 \%$ CI: 2,0-3,0) [7]. Kwestią kontrowersyjną jest natomiast podłoże łysienia plackowatego u pacjentów z łuszczycą. Nie wykazano, czy jest to schorzenie współistniejące czy też niepożądana reakcja indukowana przez stosowane u pacjentów leki przeciwłuszczycowe, takie jak infliksymab, efalizumab, etanercept, alefacept i cyklosporyna [2].

W powyższym opisie przypadku przedstawiono przykład współwystępowania twardziny ograniczonej, łuszczycy i łysienia plackowatego u jednej pacjentki. Współwystępowanie tych trzech chorób nie było dotychczas opisywane w piśmiennictwie. Niezbędne są dalsze badania ukierunkowane na wyjaśnienie ewentualnej zależności między tymi trzema zaburzeniami w odniesieniu do charakterystycznych szlaków procesu zapalnego i autoimmunizacji.

\section{KONFLIKT INTERESÓW}

Autorzy nie zgłaszają konfliktu interesów.

\section{References}

\section{Piśmiennictwo}

1. Saleh Z., Arayssi T., Saleh Z., Ghosn S.: Superficial morphea: 20-year follow up in a patient with concomitant psoriasis vulgaris. J Cutan Pathol 2009, 36, 1105-1108.

2. Verros C., Rallis E., Crowe M..: Alopecia areata during ustekinumab administration: co-existence or an adverse reaction. Dermatol Online J 2012, 18, 14.

3. Furue K., Ito T., Tsuji G., Kadono T., Nakahara T., Furue M.: Autoimmunity and autoimmune co-morbidities in psoriasis. Immunology 2018, 154, 21-27.

4. Corral Magaña O., Escalas Taberner J., Escudero Góngora M.M., Giacaman Contreras A.: Morphea in a patient with psoriasis on treatment with ustekinumab: comorbidity or adverse effect. Actas Dermosifiliogr 2017, 108, 487-489.

5. Harrison B., Herrick A., Griffiths C.: Psoriasis and diffuse systemic sclerosis: a report of three patients. Rheumatology 2000, $39,213-215$.

6. Kreuter A., Wischnewski J., Terras S., Altmeyer P., Stücker M., Gambichler T.: Coexistence of lichen sclerosus and morphea: a retrospective analysis of 472 patients with localized scleroderma from a German tertiary referral center. J Am Acad Dermatol $2012,67,1157-1162$

7. Wu J.J., Nguyen T.U., Poon K.Y., Herrinton L.J.: The association of psoriasis with autoimmune diseases. J Am Acad Dermatol $2012,67,924-930$.

How to cite this article

Durmaz K., Ataseven A., Özer I., Oltulu P.: Alopecia areata, morphea and psoriasis. Dermatol Rev/Przegl Dermatol 2020, 107, 289-291. DOI: https://doi.org/10.5114/dr.2020.97761. 